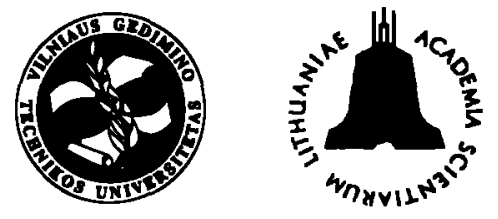

JOURNAL OF CIVIL ENGINEERING AND MANAGEMENT

http:/www.vtu.lt/english/editions

2003, Vol IX, No 2, 98-103

\title{
CORRECTION OF A DESIGNED BUILDING'S HEAT BALANCE ACCORDING TO ITS REAL HEAT CONSUMPTION
}

\author{
Kestutis Čiuprinskas', Vytautas Martinaitis ${ }^{2}$ \\ Dept of Heating and Ventilation, Vilnius Gediminas Technical University, \\ Saulètekio al.11,LT-2040 Vilnius, Lithuania. 'E-mail: kc@ap.vtu.lt; ${ }^{2} E$-mail: vm@k354.stp.lt
}

Received 25 July 2002; accepted 16 Jan 2003

\begin{abstract}
One of the most important issues in the implementation of energy saving measures is a proper evaluation of possible energy savings. If energy savings are overestimated in an energy audit (EA), a situation may occur where after the renovation, the implemented energy saving measures is not paid back or their pay back time is longer than expected before the funds (mostly loaned) were invested. To avoid such a situation, the procedure of a building's energy audit should involve the correction of calculated heat balance according to its real heat consumption, recalculated to the normative conditions. In manipulating different building parameters of not exact meanings, it is necessary to attain that the building's heat demand before renovation (theoretically calculated by the same methodology and parameters as demand after renovation) would be as close as possible to the actual heat consumption, recalculated under normative conditions. Only after such a fitting of the actual and theoretical heat demands (decomposition of building heat balance and correction of its components) is it possible to have a reasonable assessment of the feasible heat savings, after the implementation of heat saving measures.

The aim of this work is to disclose some peculiarities of building heat balance that is used for energy audit calculations of existing buildings, to offer a calculation methodology evaluating these peculiarities, to show evidently the importance of the investigated problem.
\end{abstract}

Keywords: methodology of energy audit, evaluation of energy saving, heat consumption, heat balance.

\section{Introduction}

In Lithuania $53 \%$ of final energy is consumed for the heating of buildings. A half of this amount is supplied by district heating systems. According to preliminary estimations the owners of buildings pay over 2 billion Litas for heating and about 0,5 billion yearly for electricity. These quantities depend greatly on energy using efficiency and are important for Lithuania's economical, social and environmental situations and their development. The strategy of the European Community until 2010 in this direction is stated in Energy Efficiency Action Plan, based on a report about the energy efficiency of the European Commission [1-5]. This Plan covers measures for energy efficiency integration into the Community policy and the reinforcement of the present policy. The main statements of the newly initiated Directive for a building's energy characteristics will definitely make an influence on the implementation and measures taken by Lithuanian Energy efficiency policy [6]. The European Community performed a study of the Energy Efficiency policy in the European Union countries [7], and the main attention in this work was paid to the administration of the national energy audit (EA) and similar programmes, their legislative environment, subsidy system policy, the main participants and the implementation experience.

One of the most important issues in the implementation of energy saving measures is a proper evaluation of possible energy savings. If these savings are overestimated in an energy audit, a situation may occur where, after the renovation, the implemented energy saving measures are not paid back or their pay back time is longer than expected before the funds (mostly loaned) were invested. This situation damages consumer interests and the prestige of energy efficiency programmes and energy consultants. The authors of this article, together with other specialists of buildings and their systems, have made a number of researches, methodical and practical works related to building energy audits [8-13].

The aim of this work is to disclose some peculiarities of building heat balance that is used for energy audit calculations of existing buildings, to offer a calculation methodology evaluating these peculiarities, to show evidently the importance of investigated problem. 


\section{Problem}

For a correct evaluation of possible heat savings, it is necessary to know the building heat consumption before and the designed heat demand after the installation of heat saving measures. The implementation of this simple principle depends on several factors. First of all, these two quantities can be compared only if they are determined under the same conditions. It is most useful when the heat demand and consumption are (re)calculated for the so-called normative conditions, when the outdoor and indoor air temperatures satisfy the normative requirements. Generally, the actual indoor and outdoor air temperatures never match such conditions and therefore the actual heat consumption should always be recalculated for the normative conditions.

In Lithuania, as distinct from other West European countries, energy audits were started when all buildings consuming the heat from the district heating network (or natural gas network as heat source) had already installed the heat (or gas) meters. Thus, energy consumers and energy consultants had the possibility to compare the energy consumption before and after the implementation of energy saving measures. However, as experience and practice showed [14], both consultants and consumers made many mistakes. This could be explained by the absence of methodological base, unity of content and form, or just a lack of knowledge when performing these estimations. Some energy consultants used only heat demand calculations without an analysis of actual consumption data.

As international practice confirms, the measurements of heat transfer coefficients (U-values) of a building envelope are not usually included in a "normal" energy audit (as it is not a scientific investigation), though these values are used in calculations of every, even the simplest, energy audit. The same could be said about dimensions of a building and its external partitions, their air-tightness and air change rates of premises. The calculated heat demand depends significantly on these parameters and so the accepting of some values, even of a possible limited range, can cause deviations of up to some tens percent.

Effective utilisation of heat gain from such sources as the sun, people and household appliances depend on the control level of the heating system. As a rule, improved automatics and regulated by consumers control equipment take place among the energy saving measures recommended in EA report. This causes a reduction of heat consumption independently of the thermal characteristics of a building envelope.

For a correct selection of energy saving measures and the evaluation of their efficiency, the consumed and calculated heat amounts "before" and "after" renovation should be divided into components. The number of these components should be not less than the number of supposed energy saving measures (more is better). This division process and balancing of actual and calculated heat consumption before renovation (by choosing and correcting the thermal properties of a building envelope, air change rate, taking into account indoor and outdoor temperatures, heating system regulation type, etc) is the methodological basis for solving the investigated problem.

Only after such a fitting of the actual heat consumption and theoretical heat demand it is possible to reasonably assess the feasible heat savings, after the implementation of heat saving measures.

\section{Methodology}

Energy saving calculations usually should be made for several buildings, in a short term and not so detailed as during the design of the building heating system. Therefore it is necessary to have a methodology that allows one to perform calculations based on aggregated data with a possibility to divide the total heat demand among building elements and the processes of a building.

Usually calculation methods of heat demand and the designed capacity $[15,16]$ are not adopted for such calculations, because they provide no possibility to determine the capacity of the heating system and the heat consumption for the whole building at once, using, for example, total areas of each partition type (walls, windows, roof, floor) and total air change of building, but not calculating that for each room and each partition, thermal bridge and air volume of this room.

The base of the methodology presented here was elaborated in the Heating and Ventilation department of Vilnius Gediminas Technical University [17, 18]. Although it is based on aggregated data, it is precise enough [19] to be used for checking and evaluating the real heat consumption, for an analysis of buildings that have no registered heat consumption or when the registered data are not reliable. This methodology is not suitable for designing the building heating systems, because it provides no possibility to calculate heat losses of individual premises. The main target of this methodology is multistoried residential buildings but with some reservation it could also be used for public buildings. Due to the mentioned reasons this methodology was chosen, modified and supplemented for a better adaptation to a building energy audit and the computer program GGNEVA [8], as was created for energy consultants. Here are presented only essential moments of this methodology, illustrated by fragments of the GGNEVA program.

\section{Heat balance of building}

The equation of a building heat balance for a certain period can be expressed as follows (on the one side of the equation - the gained heat, on the other side - the lost heat):

$$
\begin{gathered}
Q_{\text {loss }}+Q_{d h w p}=Q_{h s}+Q_{d h w s}+Q_{\text {gain }} \quad \text { or } \\
Q_{e n v}+Q_{v e n t}+Q_{d h w p}=Q_{h s}+Q_{d h w p}+Q_{d h w n}+Q_{\text {gain }}
\end{gathered}
$$


where $Q_{\text {loss }}$ - building heat losses; $Q_{e n v}$ - heat losses through building partitions (envelope); $Q_{v e n t}$ - heat losses with ventilation; $Q_{d h w p}-$ heat consumption for DHW preparation; $Q_{h s}$ - heat supplied to building by heating system; $Q_{d h u s}-$ heat supplied to building by DHW system; $Q_{d h w n}$ - heat transmitted to building from DHW pipe network; $Q_{\text {gain }}$ - heat gains from the sun, people and household appliances.

Attention should be paid that only $Q_{h s}$ or sum $Q_{h s}+Q_{d h w s}$ can by determined by heat meters. Heat consumption for domestic hot water (DHW) preparation is determined partly by meters and partly by calculations. Other quantities can only be calculated or evaluated.

\subsection{Calculated part of a building heat balance}

Building heat losses (MWh) of the investigated period can be calculated as follows [8]:

$$
\begin{gathered}
Q_{\text {env }}=\sum_{i} U_{i} \cdot A_{i} \cdot n_{i} \cdot \beta_{1} \cdot \beta_{2} \cdot D D_{n} \cdot 24 \cdot 10^{-6} ; \\
Q_{v e n t}=V_{p r e m} \cdot n_{a c} \cdot \rho_{i a} \cdot c_{p a} \cdot \beta_{2} \cdot D D_{n} \cdot 24 \cdot 10^{-6} / 3,6 ;(4)
\end{gathered}
$$

where $i$ - partition; $U$ - heat transfer coefficient of partition $\left(\mathrm{W} / \mathrm{m}^{2} \mathrm{~K}\right) ; A$ - area of partition $\left(\mathrm{m}^{2}\right.$; taking into account linear thermal bridges, dimensions of partitions must be determined according the requirements of present norms); $n$ - coefficient evaluating the partition contact with outdoor air; $\beta_{1}-$ coefficient (only for the vertical barriers) evaluating the building configuration, its orientation from the viewpoint of world sides and wind impact; $\beta_{2}$ - coefficient evaluating the additional heat losses from uninsulated network pipes in the non-heated premises, etc.; $D D_{n}$ - normative degree-days number of investigated period; $V_{\text {prem }}-$ volume of all premises $\left(\mathrm{m}^{3}\right)$; $n_{a c}$ - air change rate $(1 / \mathrm{h}) ; \rho_{i a}-$ air density in premises $\left(\mathrm{kg} / \mathrm{m}^{3}\right) ; c_{p a}-$ air specific heat $\left(\mathrm{kJ} / \mathrm{kg}^{\circ} \mathrm{C}\right)$.

In residential buildings the heat gains from people and domestic appliances are proportional to the area of living rooms and kitchens. It is assumed that sum of heat gained from the sun, people and household appliances is $50 \mathrm{kWh} / \mathrm{m}^{2}$ of the total area per heating season. Per day it would be $0,25 \mathrm{kWh} / \mathrm{m}^{2}$ and that corresponds to the average heat gain flow of about $10 \mathrm{~W} / \mathrm{m}^{2}$.

$$
Q_{\text {gain }}=025 \cdot A \cdot z ; \quad(\mathrm{kWh})
$$

where $A$ - total heated area $\left(\mathrm{m}^{2}\right) ; z$ - duration of investigated period in days.

If circulation in the DHW system is permanent, heat flow from this network is almost constant during the year. In spite of that, it is very difficult to determine the real heat amount transferred from the DHW network to the building, because there is usually no separate heat meter for the DHW, amounts of supply and return water are different, and the temperature of the returned water is

\begin{tabular}{|c|c|c|c|c|c|c|c|}
\hline \multirow{2}{*}{ Barriers } & \multicolumn{2}{|c|}{$\mathbf{U} \mathrm{W} /(\mathrm{m} 2 \mathrm{~K})$} & \multicolumn{2}{|c|}{ Surface } & \multicolumn{3}{|c|}{ Heat Consump. [MWh] } \\
\hline & actual & renov. & $n$ & $A[\mathrm{~m} 2]$ & Qact & Qrenov & $\Delta$ \\
\hline walls & 0,91 & 0,91 & 1,00 & 2109,15 & 196,05 & 196,05 & \\
\hline windows & 2,56 & 1,40 & 1,00 & 565,50 & 147,87 & 80,87 & 67,00 \\
\hline roof & 0,60 & 0,25 & 1,00 & 672,40 & 38,16 & 15,90 & 22,26 \\
\hline floor & 0,60 & 0,33 & 0,60 & 672,40 & 22,89 & 12,59 & 10,30 \\
\hline stair's wind. & 2,56 & 1,90 & 1,00 & 44,00 & 11,51 & 8,54 & 2,97 \\
\hline ext. doors & 3,00 & 3,00 & 1,00 & 8,80 & 2,70 & 2,70 & \\
\hline average & 1,02 & 0,77 & $\Sigma_{\text {surf }}=$ & 4072,25 & 419,18 & 316,64 & 102,53 \\
\hline air change & 1,00 & 0,50 & $V_{\text {spac }}$ & 8573,10 & 273,22 & 136,61 & 136,61 \\
\hline \multirow{2}{*}{\multicolumn{5}{|c|}{ Qchar (kWh/DD) }} & 186,24 & 121,92 & 64,32 \\
\hline \multirow{4}{*}{\multicolumn{5}{|c|}{$\begin{array}{r}\mathbf{Q} \text { ga in } \\
\mathbf{Q} \text { DHW pipes } \\
\mathbf{Q} \text { add. used } \\
\text { heating system) }\end{array}$}} & $-164,09$ & $-164,09$ & \\
\hline & & & & & $-46,46$ & $-36,64$ & $-9,82$ \\
\hline & & & & & $-126,65$ & $-182,26$ & 55,61 \\
\hline & & & & & 564,14 & 271,42 & 292,72 \\
\hline
\end{tabular}
unknown (load of circulation line during the day is not constant). Therefore this amount of heat is usually cal-
Fig 1. Worksheet "Theoretical" of the program GGNEVA

culated using equations of heat transfer. It can be used such a simplified equation:

$$
Q_{d h w n}=\alpha_{n} \cdot l_{d h w n} \cdot 24 \cdot z / 1000 ;(\mathrm{kWh})
$$

where $\alpha_{n}$ - coefficient of heat transfer from the network of DHW, assuming that average diameter of pipes is $20 \mathrm{~mm}$, and average difference of temperatures of pipe and its environment is $30^{\circ} \mathrm{C}, \alpha_{n}=30 \mathrm{~W} / \mathrm{m} ; l_{d h w n}$ - total length of insulated DHW pipes in building.

In multi-storey residential buildings the heat amount transferred from the DHW network is often equal to and sometimes even greater than the heat consumption for a DHW preparation. Theoretical calculations as well as practical experience may confirm that [20-22]. It is obvious that this heat amount participates in the building heating, but it is emitted only in bathrooms and pipe niches.

In the GGNEVA program the worksheet "Theoretical" is designed for the theoretical calculation of a building heat losses (Fig 1). Both the capacity of a heating system and the annual heat consumption are calculated for two situations - actual (before renovation) and future, when heat saving measures will be implemented. Also, heat savings of each building component and total savings are presented here.

\subsection{Treatment of actual heat consumption data}

Actual heat consumption of a heating system is determined as the difference in indications of a heat meter. Depending on what heat consumption is metered - total or only of the heating system, the equations differ:

$$
Q_{h s}=\Delta_{h} ; \text { or } Q_{h \mathrm{~s}}=\Delta_{h}-Q_{d h w p}-Q_{d h w n}
$$

$Q_{d h w p}=\Delta_{d h w} \cdot \rho_{w} \cdot c_{p w} \cdot\left(t_{h w}-t_{c w}\right) / 3600 ;(\mathrm{kWh})$

where $\Delta_{h}$ - difference in indications of heat meter during investigated period $(\mathrm{kWh}) ; \Delta_{d h \mathrm{w}}$ - difference in indications of DHW meter during investigated period $\left(\mathrm{m}^{3}\right)$; $t_{h w}$ - temperature of prepared hot water; $t_{c w}$ - temperature of cold water supplied to the building; $\rho_{w}$ - density of water $\left(\mathrm{kg} / \mathrm{m}^{3}\right) ; c_{p w}$ - specific heat of water $(\mathrm{kJ} / \mathrm{kgK})$. 


\begin{tabular}{|c|c|c|c|c|c|c|c|c|c|c|c|}
\hline Begin & End & $\Sigma$ & avrg & $\Sigma$ & $\Sigma$ & $\Sigma$ & avrg. & $\Sigma$ & $\Sigma$ & $\Sigma$ & avrg. \\
\hline 97.10 .01 & 98.04 .30 & 212 & 1,3 & 3541 & 580000 & 1505 & 7,075 & 86520 & 46635 & 446845 & 192,78 \\
\hline \hline \hline Begin & End & $\begin{array}{c}\text { Nb. } \\
\text { of } \\
\text { days }\end{array}$ & $\begin{array}{c}\text { Text } \\
\text { ave } \\
\text { rage }\end{array}$ & $\begin{array}{c}\text { Deg } \\
\text { ree } \\
\text { Days }\end{array}$ & $\begin{array}{c}\text { Total } \\
\text { heat, } \\
{[\mathrm{kWh}]}\end{array}$ & $\begin{array}{c}\mathrm{DHW}, \\
{[\mathrm{m} 3]}\end{array}$ & $\begin{array}{c}\mathrm{DHW}, \\
{[\mathrm{m} 3 /} \\
\text { day] }\end{array}$ & $\begin{array}{c}\mathrm{DHW}, \\
{[\mathrm{kWh}]}\end{array}$ & $\begin{array}{c}\text { DHW } \\
\text { pipes } \\
{[\mathrm{kWh}]}\end{array}$ & $\begin{array}{c}\text { Heating } \\
\text { system, } \\
{[\mathrm{kWh} \text { ] }}\end{array}$ & $\begin{array}{c}\text { Heat } \\
\text { loss } \\
\text { charact. } \\
\mathrm{kWh} / \mathrm{DD}\end{array}$ \\
\hline \hline 97.10 .01 & 97.10 .31 & 31 & 4,9 & 407 & 46000 & 215,0 & 6,935 & 12360 & 6819 & 26821 & 141,69 \\
\hline 97.11 .01 & 97.11 .30 & 30 & 1,4 & 497 & 77000 & 215,0 & 7,167 & 12360 & 6599 & 58041 & 177,06 \\
\hline 97.12 .01 & 97.12 .31 & 31 & $-4,4$ & 694 & 122000 & 215,0 & 6,935 & 12360 & 6819 & 102821 & 192,60 \\
\hline 98.01 .01 & 98.01 .31 & 31 & $-0,8$ & 584 & 96000 & 215,0 & 6,935 & 12360 & 6819 & 76821 & 184,52 \\
\hline 98.02 .01 & 98.02 .28 & 28 & 0,0 & 504 & 86000 & 215,0 & 7,679 & 12360 & 6159 & 67481 & 189,35 \\
\hline 98.03 .01 & 98.03 .31 & 31 & $-0,7$ & 581 & 80000 & 215,0 & 6,935 & 12360 & 6819 & 60821 & 157,98 \\
\hline 98.04 .01 & 98.04 .30 & 30 & 8,9 & 274 & 73000 & 215,0 & 7,167 & 12360 & 6599 & 54041 & 306,27 \\
\hline
\end{tabular}

for the described analysis is one week. This duration of registration period allows to have about 25 points for analysis per heating season and to avoid distortion in the transitional months of the heating season or when supply of DHW is out of order. The period shorter than one week is unacceptable because of heat inertia and behaviour of users (espe-

Fig 2. Worksheet "Periods" of the program GGNEVA

Heat consumption for a DHW preparation can be easily calculated according to the data of the central DHW meter. If there is no such a meter, data from individual DHW meters can be used (taking into account their reliability). If there are no DHW meters in a building, but there is a common heat meter, the approximate heat consumption in the DHW system can be determined by the heat consumption data taken during the summer period.

The base of analysis of actual heat consumption is the data of the past periods. The more periods are analysed, the better (more accurate) results could be obtained. In practice the most common period for registering of heat consumption is one month, because the bills for consumed heat usually come monthly. In this case there are only 7 points for analysis during the heating season (in Lithuania - from October to April). Two points should be rejected because buildings are not heated through the entire months of transitional period. Information of the rest 5 points usually is too aggregated (variations of heat consumption during the month is smoothed). In our opinion, the ideal registration period

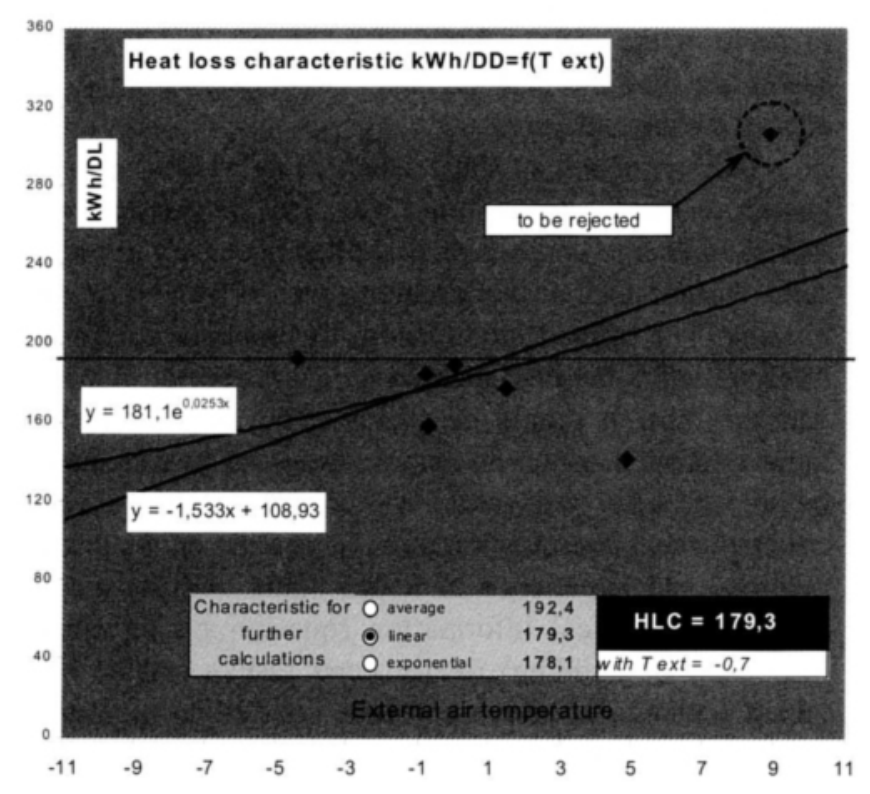

Fig 3. Worksheet "Characteristic" of the program GGNEVA cially in DHW consumption) in the building.

The example of a periods data is shown in Fig 2 . The result of an analysis of each period - the so-called building Heat Losses Characteristic (HLC), which indicates physical building heat losses per unit of degreedays at a certain outdoor temperature. The dependence of HLC on the outdoor temperature is examined in the GGNEVA worksheet "Characteristic" (Fig 3). In the ideal case, the points (point is HLC of the period) should be located in one horizontal line, ie the building should consume the same amount of heat per one degree day, independently of the outdoor temperature. In reality such a situation never happens - even if points are approximately in a horizontal line, their distribution across the vertical axis is usually significant. That means that it is impossible to say exactly how much heat the building will consume in reality when the outdoor temperature is of a certain value. The answer can be only statistical and therefore the regression analysis is used.

The presented graph can be very informative for an experienced specialist. According to the character of the curves some heat consumption problems can be diagnosed. For instance, a great distribution of points by vertical axis shows an inefficient operation of control equipment (automatics) of the heating system. Inclination of the curves indicates that under some outdoor temperatures the building is either overheated or underheated. But the main purpose of this graph is to notice the evident anomalies in general and the unreal data of some periods. Thus the identified wrong point can be rejected, or data of this point can be corrected.

For obtaining the convergence between the calculated heat demand and the factual heat consumption, recalculated under normative conditions, or, in other words, for correcting a designed heat balance, the worksheet "Fitting" is designed (Fig 4). Here, in one place all the main calculation parameters can be corrected (eg properties of building partitions, air change and heat gain rates, temperatures of hot and cold water, type of heating system regulation). Besides the data input area, there is a laconic result area, in which the calculated heat demand and the actual heat consumption before renovation (recalculated to the normative conditions), the difference between them, calculated heat demand after renovation and heat savings are presented. 


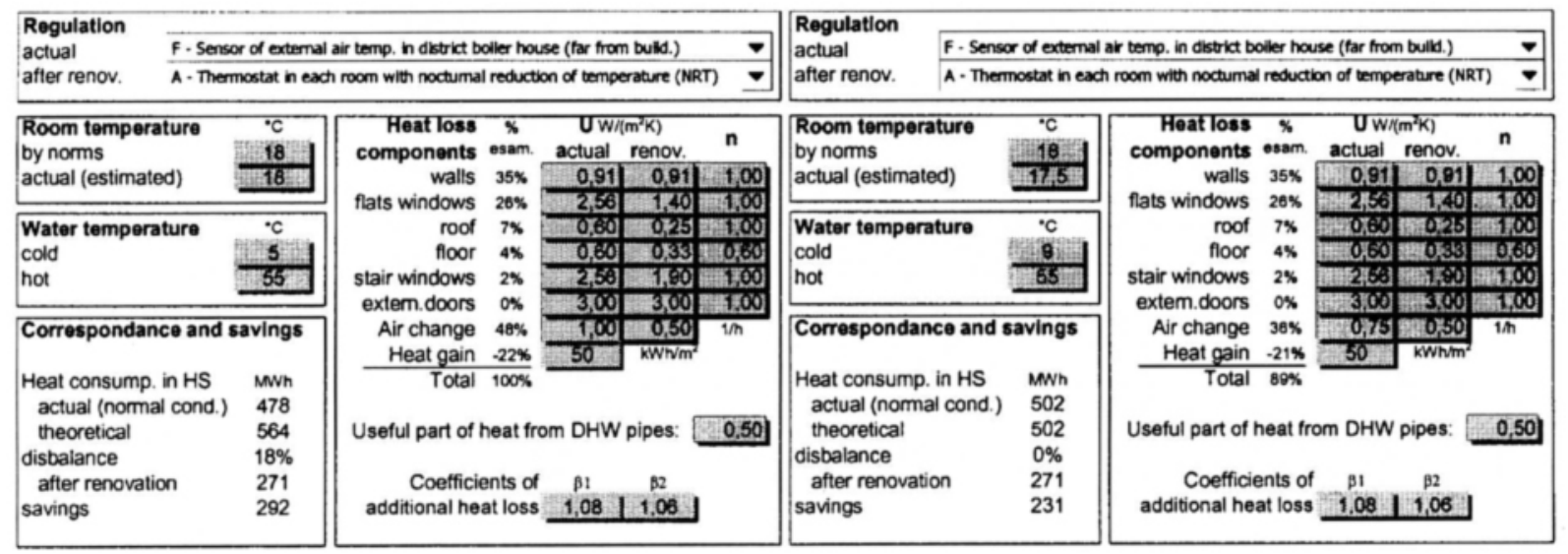

Fig 4. Worksheet "Fitting" of the program GGNEVA with data of the analysed example: before (on the left) and after (on the right) correction of building heat balance

In Fig 4 the results of the analysed example before and after correction are presented. It can be seen that before correction (on the left) the calculated heat demand is $18 \%$ greater than the actual heat consumption and it is not obvious which value can be trusted. On the right side of the figure, the results are presented after correction.

In this case, the calculated heat demand and the actual heat consumption coincide. In this example this is reached by a correction of the cold water temperature, air change rate and the average temperature of the premises.

In Table 1 more detailed results of this example are presented. It is seen that the expected heat savings without correction is $61 \mathrm{MWh}$ greater than savings calculated after the correction. Thus, the difference between values is $26 \%$. Naturally, convergence can be reached also by manipulation of other parameters, so the energy consultant can never be sure that the obtained results after correction are absolutely exact. But anyhow, after such a correction the results will be much more reliable than without any correction at all. Also, they will be more reliable compared with results obtained by using calculations only, without an analysis of the real heat consumption.

Table 1. The results of heat consumption and savings of the analysed example

\begin{tabular}{|c|c|c|}
\hline Heat consumption (MWh) & not corrected & corrected \\
\hline actual (norm. conditions) & 478 & 502 \\
\hline theoretical (calculated) & 564 & 502 \\
\hline Heat saving & 292 & 231 \\
\hline compared with actual cons. & $61 \%$ & $46 \%$ \\
\hline compared with calc. demand & $52 \%$ & $46 \%$ \\
\hline Error in saving evaluation & $61(26 \%)$ & - \\
\hline
\end{tabular}

\section{Generalisation}

The procedure of a building energy audit should involve the correction of calculated heat balance according to its real heat consumption, recalculated to the nor- mative conditions. In the manipulating different building parameters of not exact meanings, it is necessary to attain that the building heat demand before renovation (theoretically calculated by the same methodology and parameters as demand after renovation) would be as close as possible to the actual heat consumption, recalculated under normative conditions. Only after such a fitting of the actual and theoretical heat demands (decomposition of building heat balance and correction of its components) is it possible to have a reasonable assessment of the feasible heat savings, after the implementation of heat saving measures.

The methodology of a building heat demand calculation, in the frame of the described problem, is not the most important thing, because the correction of the designed heat balance according to the real heat consumption is necessary by using any "theoretical" methodology. It is obvious that this correction is possible for existing buildings only, when the real heat consumption is available (it is better if more than one year). These calculations are necessary for energy consultants who need to perform the energy audit of an entire building and assess the possible heat savings after implementation of energy saving measures.

The correction of data, when exact values are not known, is hardly a justifiable way. But in practical activities of energy consultants it is often necessary to make some assumptions and evaluations even if some data are missing. The offered methodology is probably not absolutely reliable, because there is no exact receipt of what data and how it should be changed, but it is definitely more reliable than the direct calculation of heat demand before and after renovation without any correction according to real consumption data. Depending on the qualifications and experience of a consultant and the available non-numerical information (questioning of users, inspection of building), really good results can be obtained without expensive and time-consuming measurements. 


\section{References}

1. European Commission's Common Energy Policy: Energy efficiency: towards a strategy for the rational use of energy. 1998. 246 p.

2. European Commission's Communication: An overall view of energy policy and actions. 1997. $167 \mathrm{p}$.

3. European Commission's implementing measures. Construction. Energy certification of buildings. Official Journal of the European Communities L 237, 22091993.

4. European Commission's Proposal: Energy efficiency Energy performance of buildings. 2001. $226 \mathrm{p}$.

5. European Commission's Proposal: Energy Efficiency Action Plan. 2000. 247 p.

6. Kazakevičius, E.; Vitkauskas, A.; Mikkelsen, S. E. Lithuanian energy efficiency project. Energy Policy, Vol 30, issue 7, Elsevier Science, 2002, p. 621-627.

7. SAVE-Project Final Report. Energy Audit Management Procedures. 2000. $348 \mathrm{p}$.

8. Computer program "Quick Energy Audit of Residential Building" and its user's guide (Kompiuterio programa "Greitas gyvenamojo namo energijos vartojimo auditas (GGNEVA)“ ir jos vartojimo vadovas). Report of research work. Vilnius: Vilnius Gediminas Technical University, 2000. 26 p. (in Lithuanian)

9. Investigation of renovation possibilities of Lithuanian school buildings (Lietuvos bendrojo lavinimo mokykly pastaty atnaujinimo galimybių tyrimas). Report of research work. Vilnius: Vilnius Gediminas Technical University, 2000. 62 p. (in Lithuanian).

10. Collection and analyzing the data of energy audits and monitoring order and experience in foreign countries and preparation of proposals for establishing such order in Lithuania (Duomenu apie tvarką ir patirti vykdant energetinius auditus ir monitoringus užsienio šalyse surinkimas ir analizè bei pasiūlymu tokiai tvarkai nustatyti mūsų šalyje parengimas). Report of research work. Vilnius: Vilnius Gediminas Technical University, 2001. 82 p. (in Lithuanian).

11. Short-term consultation achieving to prepare the energy audits methodology for educational institutions (Trumpalaike konsultacija siekiant nustatyti renovuotinu švietimo istaigu energetiniu audity rengimo metodika). Report ordered by Ministry of Education and Science. Vilnius: JSC EKSERGIJA, 2001. 36 p. (in Lithuanian)

12. Short-term consultation achieving to review and analyze the experience of recently renovated Lithuanian schools (Trumpalaikè konsultacija siekiant peržiūreti ir išanalizuoti neseniai renovuotu Lietuvos mokyklu patirti). Report ordered by Ministry of Education and Science. Vilnius: JSC EKSERGIJA, 2001. 350 p. (in Lithuanian).
13. Martinaitis, V. Analytic calculation of degree-days for the regulated heating season. Energy and Buildings, Vol 28, issue 2, Elsevier Science, 1998, p. 185-189.

14. Investigation of renovation efficiency in Lithuanian schools (Lietuvos bendrojo lavinimo mokyklu renovavimo priemoniu efektyvumo tyrimas). Report ordered by Ministry of Education and Science. Vilnius: JSC EKSERGIJA, 2001. 80 p. (in Lithuanian).

15. STR 2.09.04:2000. Power demand for building heating system. Heat consumption (Pastato šildymo sistemos galia. Šilumos suvartojimas). Vilnius: Lithuanian Ministry of Environment, 2000. 26 p. (in Lithuanian).

16. EN832. Thermal performance of buildings - Calculation of energy use for heating - Residential buildings. Brussels: CEN, 1998. $50 \mathrm{p}$.

17. Gedgaudas, M.; Paulauskaité, S. Heat consumption for heating residential buildings (Šilumos sąnaudos gyvenamuju pastatų šildymui). Environmental engineering (Aplinkos inžinerija), 1995, No 1(3), p. 54-57 (in Lithuanian).

18. Gedgaudas, M.; Paulauskaitè, S.; Čiuprinskienè, J. Methodology for determining the annual heat demand using the aggregated data (Методика определения годового теплопотребления в жилых зданиях по укрупненным показателям). In: Problems of building thermo-physics related to microclimatic systems and energy saving: Materials of 5-th conference, April 26-28, 2000. Moscow: NIISF, 2000, p. 61-66 (in Russian).

19. Paulauskaitė, S.; Gedgaudas, M.; Martinaitis, V. Analysis and evaluation of building heat consumption and retrofitting pay back calculation methodologies (Šilumos suvartojimo pastate ir atitvaru apšiltinimo atsiperkamumo metodiku analizè ir ivertinimas). Report of scientific work. Vilnius: Vilnius Gediminas Technical University, 1998. 23 p. (in Lithuanian).

20. Paulionis, K. Analysis of heat consumption in domestic hot water systems (Šilumos sąnaudų karštojo vandentiekio sistemose analizè). Heat engineering (Šiluminè technika), 2000, No 6, p. 8-10 (in Lithuanian).

21. Martinaitis, V.; Karlonaite, G.; Čiuprinskas, K. Energy analysis of the appartment buildings Antakalnio 64 and 66, Vilnius. Project 1055. Vilnius: JSC EKSERGIJA 1999. $48 \mathrm{p}$.

22. Martinaitis, V. Correction of design codes of domestic hot water consumption (Karšto vandens suvartojimo normy tikslinimas). Report ordered by Energy Saving Direction, Ministry of Energetics. Vilnius: Vilnius Gediminas Technical University, 1996. 36 p. (in Lithuanian). 